\title{
The Role of Economical Concentrations in the Contemporary Competitive Equation
}

\author{
Anca Popescu-Cruceru1* Eugenia-Gabriela Leuciuc ${ }^{2}$, Viorel Bănulescu ${ }^{3}$
}

${ }^{1}$ Artifex University of Bucharest, 47, Economu Cezărescu Street, Bucharest, Romania.

${ }^{2}$ SStefan cel Mare" University of Suceava, Faculty of Economics and Public Administration, 13th University Street, Suceava, Romania.

${ }^{3}$ Academy of Economic Studies Bucharest, Piata Romana No. 6, 1st District, 010374, Bucharest, Romania.

*For Correspondence: E-mail: ancacruceru@yahoo.com

\section{Abstract}

The ways of accomplishment of economical concentrations involve share purchasing, submissions of nominal capital increases, mergers and acquisitions of the incorporation of branches and subsidiaries, inside and/or outside the country, circumstances under which the market with a perfect competition acquires the feature of oligopoly or oligopsony. The concentration drafts have an important impact on the communitarian space and they are regulated by the European Commission, which has in its attention, in analysis, mainly the communitarian dimension, the affected market, the dominant position - such criteria used preeminently during the analysis of the economical concentration until the entrance into force of the Regulation no. 139/2004, which introduced as priority the criterion of the restriction of competition, with the exhibited resemblances in the American theory of the significant lessening of competition.

Keywords: Economical concentration, Emerging market, Restriction of competition.

\section{Introduction}

Rivalry for gaining, extending and preserving the customers can take place only under the circumstances of the economical market, while the competition becomes possible if, theoretically speaking, the idea of commerce productivity is general, and, at the socio-political level, it is ensured a functional free market. What other better way to define competition, any perspective considered, lato sensu, than the customer's ability to choose, among several alternatives, the most convenient according to his criteria of eligibility!

Competition is the active form of the free initiative itself, expressing a direct confrontation of the suppliers in order to attract customers, in the purpose of increasing the profit, by orienting in the same time towards the products and services customers' clear requests. Their demand works as a market regulator, also at the price level, by conducting, as a last resort, to an increase of the work productivity, in order to find ways as efficient as possible to gear production factors, so that it naturally decreases the weight of production costs in the final prices. Such theoretical model, unreal from a certain point of view, outlines the solidarity between competition and development, all perspectives considered economic, social, and juridical.

\section{Economical Concentrations and the Competitive Game}

Fight against monopoly detained by corporations lasted quite long; in France, for example, it became necessary the direct intervention of the state in the economic field, in order to counteract their domination, by creating the first manufactures, directly subordinated by the central administration (1791). Such fact was considered more than necessary, especially since the deregulation commerceideology was already present in England, generated by the influence of an earlier industrialization, spreading on the new continent since the foundation of the United States of America. Deregulation of trade-offs has yet met, in recent history, phases of stopping or recourse. Thus, since the beginning of the XIXth century, commercial competition has been put at risk by the most dynamic national market, that of the United States, as a consequence of the progressive concentration of capital to some dominant trusts; the same tendency appeared on the European markets, especially during the 
period between wars, the major intervention of the state in the economy becoming necessary, which also turned out to be a saving intervention, yet not prophylactic, by adopting an anti-trust legislation. In the ensemble of international affairs, there appeared tendencies to take certain protectionist measures to annihilate the attempts of competition misuse, by adopting certain binding legal provisions or, at least, for recommendation, by international organisms (UNCTAD or OMC)The purposes of competitive regulations (satisfaction of customers' demands, innovation's promotion, efficient allocation of resources, limitation of the economic power manifestation) realizes through the coordination between theoretical functions of the competition and the ways of concrete manifestation on the market. From the competition's point of view, the market appears under the form of the so-called "relevant market", since the competition can take place only on a defined relevant market. Relevant market has two fundamental dimensions: product market and geographical market, to which it is added a third dimension, that of the category of customers, in the case of competition distortions. The product market is the one describing the goods and services or their relevant substitutes [1]. As for the geographical market, this can be defined from the point of view of the customers' access to goods, located in distinct geographical areas. Differences between these components of the relevant market are yet, in most situations, hard to observe, since they are tightly related and submitted to the costumers' reactions to price increases. Typology between business operators involves two great orientations, on one side it is regarded as a proper purpose on which depends the existence of the commercial freedom on the market (the pure and perfect competition model being elaborated on the grounds of this particular conception) and, on the other side, being conceived as a necessary means for the accomplishment of certain objectives referring to the illicit distribution of resources, technical progress and stability of the working power (thesis leading to the elaboration of the "workable competition" model).

The model of the pure and perfect competition was considered as an abstract prototype, ideal and relatively rigid; such form of manifestation characterizes by atomicity, homogeneity, transparence, plurality of options, mobility of production factors and non-interference of the state.

On the pure and perfect competitive market, the price forms on the grounds of the value law action and the correlation between demand and supply. The demand becomes a variable of the price.
Under such circumstances, the price establishes at the level of balance between demand and supply: excessive demand pushes prices towards a superior level, while excessive offer attracts the decrease of the selling price of the product [2].

Once with the transition to the contemporary economic status, such theoretical model of the perfect competition hits the reality on several occasions. The gap between theory and practice is due to the phenomenon of companies concentration, which contributed to the incremental extinction of the market's atomicity, so that the state's interference in the economy increased steadily, both in internal, and in international affairs [3].

The causes of the economical concentrations can be of technical, organizational, commercial or financial order, all aiming to rationalize work, increase the development possibilities of research and innovation, decrease administrative costs, but also to create new strategies of supply and retail. From a financial point of view, companies tend to unify with other companies at the beginning of their activity, yet dynamic, needing a capital infusion in order to develop faster.

The accomplishment modalities of economical concentrations involve shares purchasing, increases of the nominal capital of the companies, mergers and acquisitions or incorporations of branches or subsidiaries inside or outside the country.

Under such circumstances, the perfect competitive market becomes both an oligopoly (limited number of sellers) and an oligopsony (limited number of purchasers).Concentration drafts having an impact on the communitarian space are regulated by the European Commission, which has in view, during the analysis, mainly the communitarian dimension, the affected market, the dominant position. They constituted the criteria of analysis of the economical concentration until the entrance into force of the Regulation 139/2004, introducing as a priority the criteria of a limited competition, also characteristic of the theory significant lessening of competition [4].

The Commission has the competence to control the non-observance of the primary and derived law and to impose the legislation in cause, aiming to its observance by the particulars, Member States and institutions. In such sense, pursuant to art. 105 para. 1 TFUE (in the domain of the competition) the Commission ensures the application of the principles related to competition established by the art. 101 and 102 TFUE, by 
investigating the supposed cases of infringement of the principles stated in the TFUE. In case of declared infringement, the Commission proposes appropriate measures in order to stop it, by imposing certain penalties and charges [5].

The control of the opportunity and equity of the sanctionary measures applied by the Commission, belong to the European Union's Court of Justice, since the decision issued by the Commission can be annulled by the Court. Yet, the Court can alter the charges established, either in the sense of increase or decrease of the punishment, but practice did not meet cases when the Court waives from the principle of non reformatio in pejus.

Economical concentrations have as a consequence the long-lasting modification over the control of the companies and, implicitly, changes on the market's structure. The means of accomplishment derive either from the merger of several independent companies, or, insidiously, from the combination of activities of several independent companies (either by ensuring a unique management, or the internal compensation of profits), also accomplished after a de facto merger. Another means of accomplishment of an economical concentration is represented by the purchase of control which mechanism, formal or informal, raises an improved attention, given the means most of the times illicit under which are hidden such forms of economical concentration.

The de jure control is relatively simple to notice; it is accomplished either after purchasings of shares, or on agreement.

De facto control is the one which, in practice, imposes detailed investigations from national and international institutions, because, regularly, such type of control exploits an economical dependency status, while the means of control exercise are indirect, as a result of certain structural connections involving external sources of financing [6].

Suspicions regarding the indirect achievement of control can be risen in the situation in which it is declared an equity of the voting right, veto right vesting, existence of a specific company quorum, with a particular calculation algorithm, especially in the case of share companies where shareholders opt for a dualist system of management, which does not exclude the issue of such manifestations of control achievement in the case (or by means) of limited liability companies.

In Information from European Union institutions and bodies (OJEU C95/2008), there was outlined, expresis verbis, the fact that while proving the de facto control there must be taken into consideration both the conventional means of control achievement, and the informal ones, of the sources of financing or family relationships type. In such sense, it is noticed the decision 98/335/EC, Commission Decision of 23 April 1997 declaring a concentration to be compatible with the common market and the functioning of the EEA Agreement (Case No IV/M.754 - Anglo American Corporation/Lonrho) - Official Journal L 14, 20/05/1998, through which the Commission conditioned the achievement by the Anglo American Corporation of South Africa Limited of a package of $24,98 \%$ of the Lonrho company, motivating that "The party to whom the trust shares may be sold should be subject to the following restrictions: the purchaser shall not be a company or person connected with either the AAC or Gencor (except if the Court of First Instance of the European Communities upholds Gencor's application in Case T 102/96 - Gencor v. Commission) groups of companies (including but not limited to all their subsidiaries, parent companies and associated companies) and members of the Oppenheimer family or any company controlled directly or indirectly by the family".Obviously that once the unique market is declared affected, the concentration is prohibited; yet, even though this does not meet all the impunity conditions, the achievement of the de facto control has a dangerous potential over the competitive game, the capital concentration by control achievement strongly influencing the regulation of market mechanisms.

It is suggestive in this sense the Commission's Decision from the 10th of June 2009 (OJEU C279/9/2009), disposing the application of a 20million euro charge for the anticipated realization of a concentration with the achievement of the exclusive control by the Electrabel S.A. Belgium company over the company Compagnie Nationale du Rhone (CNR, France).

In order to decide so, the Commission had in view the following legal situation:At the 23rd of December 2003, Electrabel, an important Belgian company in the domain of electricity belonging to the French group Suez (nowadays GDF Suez), purchased from EDF shares of the CNR company, the second company on the electricity domain in France, thus increasing the participation to the CNR company capital up to $49,95 \%$, and its voting right up to $47,92 \%$. Previously, on the $24^{\text {th }}$ of July 2003, Electrabel signed a shareholders' agreement with CDC, a company of participations controlled by the French state, which is also the second shareholder of the CNR (detaining 29,43\% of the capital and $29,80 \%$ of the voting right). 
According to this agreement, Electrabel and CDC took the engagement to vote during the Shareholders General Meetings so that the Executive Committee of CNR is composed of two representatives of the Electrabel company (out of the three members composing it), hence ensuring the majority of the Electrabel in the Administration Council.Electrabel is, in the same time, the only company of the CNR share domain and, from this perspective, it plays the central part (previously played by EDF) in the operational management of the CNR's power plants and the resulted electric energy obtained by them.The Commission considered that, in accordance to its consecrated decisional practice, on the grounds of the participation quotas during the Shareholders Meetings of the CNR from the previous years and its powerful distribution of the remaining capital, owning 47,92 \% of the voting rights, Electrabel was ensured that it disposed of a stable majority at the CNR Shareholders' Meetings.Electrabel consequently achieved an exclusive control, de facto, over the CNR company, by acquiring shares from the $\mathrm{EDF}$, former shareholder of the CNR, conclusion sustained also by the previous existence of the shareholders agreement by means of which Electrabel had the control over the Executive Committee of the CNR (the decisional organisms deciding with a simple majority strategic questions, such as annual budget and the company's business plan).As unique shareholder of the CNR, Electrabel took over the operational management of all the power plants of the CNR and the resulted electric energy trading, as a consequence of the EDF withdrawal. From such reasons, the Commission considered that Electrabel, by acquiring the exclusive control at the $23^{\text {rd }}$ of December 2003, without any prior notice and without the Commission approval, breached the art. 7para. 1 of the former Regulation regarding concentrations, which text was in force at the moment of the facts (CEE

\section{References}

1. Foster Nigel (2009) EU Law, Oxford University Press.

2. Popescu-Cruceru Anca (2006) Economic-juridic în Economia Concurențială, Economic Publishing House, Bucharest.

3. Ezrachi Ariel, Gilo David (2006) EC competition law and the regulation of passive investments among competitors, Oxford J. Legal Studies, 26(2):327-49.
Regulation no. 4064/1989 and the decisional practice of the Commission).In emergent economies the danger is as big as such game involves the economic interests which can become really excessive, perturbing free competition at a national level. It is of the national control institutions' duty to investigate attempts of de facto control achievement especially on the relevant markets of significant impact for the economy, because, as a last resort, economical concentration can achieve the connotation of a total control over it, becoming hard to correct as it has direct consequences on the prices. In the same sense, it is outlined the incidence of the norms provided by Directive 2004/25/EC regarding public offers of purchasing (OJ L 142/12, 30.3.2004), containing the minimal orientations regarding public offers for purchase of shares traded on regulated markets, applicable also in the case of control exchange, since the directive statutes principles aiming to protect the shareholders' interests but also the protection of the markets against possible manipulations and abuses.

\section{Conclusions}

The consequences of the prohibited economical concentrations produce the alteration of the perfect market and by that, they create the premises for the occurrence of the so-called imperfect competition (sufficient competition), in which oligopolistic companies end to practice a production and prices strategy aiming the achievement of profits as great as possible, so that dominant economic agents get to dictate the prices most convenient for them. The deterioration of the market relationships can also result from the character of certain operations tending to hide, under the mask of certain acquisitions and agreements between shareholders, the tendency to acquire the control.

4. Gornig Gilbert, Rusu Ioana Eleonora (2009) Dreptul Uniunii Europene, C. H. Beck Publishing House, Bucharest.

5. Militaru Ioana Nelly (2011) Dreptul Uniunii Europene. Cronologie, Izvoare, principii. Instituții, Juridical Universe Publishing House, Bucharest.

6. Gheorghiu Gheorghe, Niță Manuela (2011) Dreptul concurenței interne şi europene, Juridical Universe Publishing House, Bucharest. www.eurlex.europa.eu. 